\title{
A Comparative Study of Efficacy and Safety Between Tamsulosin and Terazosin in the Treatment of Symptomatic Benign Prostatic Hyperplasia
}

Sakhawat Mahmud Khan ${ }^{1 *}$ Md Matiar Rahaman Khan ${ }^{2}$ Shahin Akhter ${ }^{3}$ Md Mizanur Rahman ${ }^{4}$

'Department of Urology Chittagong Medical College Chittagong, Bangladesh

${ }^{2}$ Department of Surgery Chittagong Medical College Chittagong, Bangladesh.

${ }^{3}$ Department of Physiology Chittagong Medical College Chittagong, Bangladesh.

${ }^{4}$ Department of Urology Cox's Bazar Medical College Cox's Bazar, Bangladesh.
*Correspondence to:

\section{Dr. Sakhawat Mahmud Khan}

Assistant Professor

Department of Urology

Chittagong Medical College, Chittagong.

Mobile : +8801814902579

Email: k.sakhawat@ymail.com

\begin{abstract}
Background: Lower urinary tract symptoms suggestive of symptomatic Benign Prostatic Hyperplasia (BPH) are a very common disease in elderly men .The incidence of benign prostatic hyperplasia is age related. Objectives: To compare the efficacy and safety of Tamsulosin and Terazosin in the treatment of symptomatic Benign Prostatic Hyperplasia. Methods: This was a prospective study carried out in the Department of Urology, Chittagong Medial College Hospital, Chittagong, Bangladesh during the period of July to December 2014. Total 40 patients of 45-80 years of age were consequently selected according to inclusion criteria. After completion of baseline clinical evaluation and investigations, participants were divided into two groups, group A and group B. Group A $(n=20)$ was given Terazosin $1 \mathrm{mg}$ daily for 3 days at bed time and then $2 \mathrm{mg}$ daily at bed time for 2 months. Group B ( $\mathrm{n}=20)$ was given Tamsulosin, $0.4 \mathrm{mg}$ per day for 2 months. Efficacy was evaluated of each group after 2 month follow up and lastly a comparison was made between them. The parameters monitored were International Prostate Symptoms Score (IPSS) Maximum urine flow rate (Qmax) and Post Voidal Residual Volume (PVR). Tamsulosin $0.4 \mathrm{mg}$ and Terazosin $2 \mathrm{mg}$ once daily for 8 weeks both are effective in relieving symptoms of BPH but Tamsulosin is superior to Terazosin in improvement of total IPSS $(p<0.001)$ and $\operatorname{Qmax}(p<0.01)$ PVR $(p<0.01)$ at the end point. Results: Outcome of parameters at follow up after 2 months. Tamsulosin group showed significant improvement of IPSS $(\mathrm{p}<0.05)$ PVR $(\mathrm{p}<0.001)$ and $\mathrm{Qmax}(\mathrm{p}<0.001)$ than Terazosin. The incidence of adverse events by administration of Tamsulosin was less than that by Terazosin. Conclusion: Tamsulosin appears to have more efficacy and safety than Terazosin in symptomatic BPH
\end{abstract}

Key words: Tamsulosin; Terazosin; IPSS; Qmax; PVR.

\section{INTRODUCTION}

Lower urinary tract symptoms suggestive of symptomatic Benign Prostatic Hyperplasia (BPH) are a very common disease in elderly men ${ }^{1}$. The incidence of benign prostatic hyperplasia is age related ${ }^{2}$. The prevalence of histologic $\mathrm{BPH}$ in autopsy studies is about $20 \%$ in men aged $41-50$ years, $50 \%$ in men aged $51-60$ years and over $90 \%$ men above the age of 80 years $^{3}$. As life expectancy is increasing, the number of patients with symptomatic $\mathrm{BPH}$ is also increasing. The clinical manifestation of BPH included lower urinary tract symptoms, poor bladder emptying, urinary retention, detrusor instability, urinary tract infection, haematuria and renal insufficiency. Dynamic obstruction is caused by increased muscle tone of the bladder neck and prostate which is regulated by alphal adrenergic receptor ${ }^{4}$. 
A reduction in tone might be expected to reduce prostatic urethral pressure and to improve obstructive symptoms. Alpha blocker has now been prescribed for treatment of BPH for almost 20 years $^{5}$. Prostatic urethra and urinary bladder neck constitute about $70 \%$ of alpha1 receptor ${ }^{6}$. Medical treatment for $\mathrm{BPH}$ may be in the form of alpha receptor blockers and 5 alpha reductase inhibitors. But it is now well known that alpha receptor blockers (Like Terazosin, Tamsulosin) is safe and more effective than 5 alpha reductase inhibitors and combination of the two ${ }^{7}$. Over the last decade, the incidence of surgery has declined in almost all countries and the incidence of medical treatments rising ${ }^{8}$. The goal of the study was to find out safety of a blockers to improve the IPSS score, Qmax and PVR, in symptomatic BPH.

\section{MATERIALS AND METHODS}

This was a prospective study conducted in the Department of Urology, Chittagong Medical College Hospital, Chittagong from July to December 2014. The method and purpose of the study were explained to the patients and only those who agreed were finally selected. Written consent was taken from each respondent. The inclusion criteria were: male between 45-80 years, IPSS 8 to 19 , PVR 50 to 100 $\mathrm{ml}$. Peak urine flow rate $(\mathrm{Qmax})$ more than $10 \mathrm{ml} / \mathrm{sec}$ but less than or equal to $15 \mathrm{ml} / \mathrm{sec}$, voided volume of at least $150 \mathrm{ml}$. Patients with carcinoma prostate, refractory retention of urine, recent U.T.I, recent gross haematuria, bladder stone, hydroureteronephrosis, renal insufficiency (Serum creatinine $>2 \mathrm{mg} / \mathrm{dl}$ ) large bladder diverticula, neurogenic bladder, stricture urethrae were excluded from the study.

A total 40 patient were randomly selected for this study, they were numbered in 1 to 40 . Odd numbers were considered as terazosin (Group A) and even number as tamsulosin (Group B). All history and examination followed a similar protocol. A detail data sheet was completed and this included particulars of the patients, results of the physical examinations and relevant baseline investigations. The patients were supplied with Bengali version IPSS sheet and they were explained and helped in expressing their symptoms in numerical representations of IPSS.

Thorough physical examination was done with special attention to urogenital system and nervous system. Blood Pressure (BP) was measured in lying and standing position to exclude postural hypotension. Digital rectal examination was done to determine the prostate size and to exclude carcinoma prostate, perianal sensation, anal tone and bulbocavernosus reflex, sensory and motor response. Jerks and reflexes were examined to detect any neurological deficit.Urine $\mathrm{R} / \mathrm{M} / \mathrm{E}, \mathrm{C} / \mathrm{S}$, PSA, Serum creatinine were done to exclude UTI, carcinoma prostate, renal failure. USG of the KUB and prostate with MCC and PVR was done to see the change in kidney,urinary stone disease, bladder wall thickness, prostate size, echotexture and any hypoechoic lesion in the prostate. Uroflow metry was considered reliable when voided volume is more than $150 \mathrm{ml}$. Plain X-ray KUB was done to exclude urinary stone disease and any lesion in the vertebral column. TC,DC,ESR, $\mathrm{Hb} \%$, serum total protein and albumin were done to exclude any side effect of terazosin and tamsulosin.
After completion of baseline clinical evaluation and investigation, participants were divided into two groups, group A and group B. Group A ( $\mathrm{n}=20$ ) was given terazosin $1 \mathrm{mg}$ daily for 3 days at bed time and then $2 \mathrm{mg}$ daily at bed time for 2 months. Group B $(n=20)$ was given tamsulosin $0.4 \mathrm{mg}$ per day for 2 months. Efficacy and safety were evaluated after 2 months and comparison was made between them. During follow up visit after 2 months BP (Both in lying and standing) was recorded. Uroflowmetry was done. USG of kidney, ureter, urinary bladder, prostate, MCC, PVR were done. IPSS score was also evaluated. Any side effects of the drugs were also recorded.

Statistical analysis was carried out using Statistical Package for Social Science (SPSS) software. All results were expressed as means \pm SD or in frequency as applicable. The results were complied and analysed using students t- test and chi-square test as appropriate. Results were considered significant if $\mathrm{p}<0.05$.

\section{RESULTS}

There was no significant difference in mean age, base line peak urine flow rate (Qmax) International Prostate Symptom Score (IPSS) and Post Voidal Residue (PVR) (Table I).

Table 1 : Comparison of base line data of two groups, Group A (Terazosin) \& Group B ( Tamsulosin).

$\begin{array}{llll}\text { Parameters } & \text { Patient group } & \text { Mean } \pm \text { SD } & \text { p value } \\ \text { Age } & \text { Terazosin }(\mathrm{n}=20) & 64.23 \pm 6.63 & 0.95 \\ & \text { Tamsulosin }(\mathrm{n}=20) & 64.13 \pm 6.29 & \\ \text { Q max } & \text { Terazosin }(\mathrm{n}=20) & 12.32 \pm 1.05 & 0.44 \\ & \text { Tamsulosin }(\mathrm{n}=20) & 12.55 \pm 2.6 & \\ \text { IPSS } & \text { Terazosin }(\mathrm{n}=20) & 15.84 \pm 1.85 & 0.78 \\ & \text { Tamsulosin }(\mathrm{n}=20) & 15.71 \pm 1.90 & \\ \text { PRV } & \text { Terazosin }(\mathrm{n}=20) & 88.55 \pm 21.28 & 0.81 \\ & \text { Tamsulosin }(\mathrm{n}=20) & 87.26 \pm 23.05 & \end{array}$

In the follow up visit after 2 months, patients treated with terazosin, mean values of IPSS, Qmax and PVR were $9.52 \pm 1.86$ points, $15.35 \pm 1.05 \mathrm{mi} / \mathrm{sec}$ and $52.58 \pm 13.10 \mathrm{ml}$ respectively. Mean value change of IPSS, Qmax and PVR were $6.32 \pm 2.90$ points, $3.03 \pm 0.98 \mathrm{ml} / \mathrm{sec}$ and $30.06 \pm 12.38 \mathrm{ml}$ respectively. In comparison to baseline mean values, IPSS, Qmax and PVR values were significantly changed $(p<0.05$ in IPSS and $\mathrm{p}<0.001$ in Qmax and PVR) (Table 2).

Table 2 : Terazosin group in follow up visit.

\begin{tabular}{|c|c|c|c|c|c|}
\hline Parameters & Baseline & $\begin{array}{l}\text { At follow } \\
\text { up }\end{array}$ & $\begin{array}{l}\text { Change } \\
\text { from } \\
\text { baseline }\end{array}$ & $\begin{array}{c}\text { Mean } \\
\text { change } \\
\%\end{array}$ & p-value \\
\hline IPSS & $15.84 \pm 1.85$ & $9.52 \pm 1.86$ & $6.32 \pm 2.90$ & $39.8 \pm 17.78$ & $p<0.05$ \\
\hline$Q \max$ & $12.32 \pm 1.05$ & $15.35 \pm 1.05$ & $3.03 \pm 0.98$ & $24.61 \pm 7.97$ & $p<0.001$ \\
\hline PVR & $88.65 \pm 21.28$ & $52.58 \pm 13.10$ & $30.06 \pm 12.38$ & $40.7 \pm 13.90$ & $\mathrm{p}<0.001$ \\
\hline
\end{tabular}


In follow up visit after 2 months, patients treated with tamsulosin, mean values of IPSS, Qmax and PVR were $8.48 \pm 1.15$ points, $16.52 \pm 1.23 \mathrm{ml} / \mathrm{sec}$ and $43.03 \pm 12.5 \mathrm{ml}$ respectively. Mean value change of IPSS, Qmax and PVR were $7.23 \pm 1.76$ points, $3.97 \pm 0.66$ and $44.23 \pm 16.91 \mathrm{ml}$ respectively in tamsulosin group. In this visit, all mean values of variables were significantly changed in comparison to baseline studies $(\mathrm{p}<0.001)$ (Table 3$)$.

Table 3 : Tamsulosin group in follow up visit.

\begin{tabular}{llllll} 
Parameters & $\begin{array}{l}\text { Baseline } \\
\text { values }\end{array}$ & $\begin{array}{c}\text { At follow } \\
\text { up visit }\end{array}$ & $\begin{array}{c}\text { Change } \\
\text { from } \\
\text { baseline }\end{array}$ & $\begin{array}{l}\text { Mean } \\
\text { change } \%\end{array}$ & p-value \\
IPSS & $15.71 \pm 1.90$ & $8.48 \pm 1.15$ & $7.23 \pm 1.76$ & $46.02 \pm 10.21$ & $\mathrm{p}<0.001$ \\
Q max & $12.55 \pm 1.26$ & $16.52 \pm 1.23$ & $3.97 \pm 0.66$ & $32.20 \pm 5.33$ & $\mathrm{p}<0.001$ \\
PVR & $87.26 \pm 23.05$ & $43.03 \pm 12.50$ & $44.23 \pm 16.91$ & $50.68 \pm 14.54$ & $\mathrm{p}<0.001$ \\
\hline
\end{tabular}

Mean percentage improvement of IPSS in terazosin group was $39.80 \pm 17.78$ points and in tamsulosin group was $46.02 \pm 10.21$ points. In comparison of IPSS change, tamsulosin group showed significantly better response than terazosin group in follow up visit $(\mathrm{p}<0.05)$ (Table 4).

Table 4 : Comparison of IPSS between the two groups in follow up visit.

$\begin{array}{llrllll}\text { Group } & \begin{array}{l}\text { Baseline } \\ \text { values }\end{array} & \begin{array}{c}\text { At follow p value } \\ \text { up visit }\end{array} & \begin{array}{l}\text { Change } \\ \text { group } \\ \text { from } \\ \text { baseline }\end{array} & \begin{array}{l}\text { Mean } \\ \text { change\% }\end{array} & \begin{array}{l}\mathrm{p} \text { value in } \\ \text { comparison } \\ \text { between } \\ \text { the two } \\ \text { groups }\end{array} \\ \text { Terazosin } & 15.84 \pm 1.85 & 9.52 \pm 1.86 & \mathrm{p}<0.001 & 6.32 \pm 2.90 & 39.80 \pm 17.78 & \mathrm{p}<0.05 \\ \text { Tamsulosin } & 15.71 \pm 1.90 & 8.48 \pm 1.15 & \mathrm{p}<0.001 & 7.23 \pm 1.76 & 46.02 \pm 10.20\end{array}$

Mean percentage improvement of Qmax in terazosin group was $24.61 \pm 7.97 \mathrm{ml} / \mathrm{sec}$ andin tamsulosin was $32.20 \pm 5.33 \mathrm{ml} / \mathrm{sec}$. In comparison tamsulosin group showed significantly higherflow rate in follow up visit $(\mathrm{p}<0.001)$ (Table 5).

Table 5 : Comparison of change of Qmax between the two groups in follow up visit.

\begin{tabular}{lllllll} 
Group & $\begin{array}{l}\text { Baseline } \\
\text { values }\end{array}$ & $\begin{array}{l}\text { At follow } \\
\text { up }\end{array}$ & $\begin{array}{l}\text { p value } \\
\text { the same } \\
\text { group }\end{array}$ & $\begin{array}{l}\text { Change } \\
\text { from } \\
\text { baseline }\end{array}$ & $\begin{array}{l}\text { Mean } \\
\text { change\% } \%\end{array}$ & $\begin{array}{l}\mathrm{p} \mathrm{value} \mathrm{in} \\
\mathbf{Q} \text { max } \\
\text { change } \\
\text { between } \\
\text { the groups }\end{array}$ \\
Terazosin & $12.32 \pm 1.05$ & $15.35 \pm 1.05$ & $\mathrm{p}<0.001$ & $3.03 \pm 0.98$ & $24.61 \pm 7.97$ & $\mathrm{p}<0.001$ \\
Tamsulosin & $12.55 \pm 1.26$ & $16.52 \pm 1.23$ & $\mathrm{p}<0.001$ & $3.97 \pm 0.66$ & $32.20 \pm 5.33$ & \\
\hline
\end{tabular}

Mean percentage reduction of PVR in terazosin group was $40.71 \pm 13.9$ and in tamsulosin it was 50.68 \pm 14.54 . In comparison of PVR change, tamsulosin group showed significantly better response than terazosin in follow up visit $(\mathrm{p}<0.001)$ (Table 6).
Table 6: Comparison of change of PVR between the two groups in follow up visit.

$\begin{array}{lllllll}\text { Group } & \begin{array}{l}\text { Baseline } \\ \text { values }\end{array} & \begin{array}{l}\text { follow up } \\ \text { values }\end{array} & \begin{array}{l}\text { p value } \\ \text { in the } \\ \text { same } \\ \text { group } \\ \text { change }\end{array} & \begin{array}{l}\text { Change } \\ \text { from } \\ \text { baseline }\end{array} & \begin{array}{l}\text { Mean } \\ \text { change\% }\end{array} & \begin{array}{l}\text { p value } \\ \text { between } \\ \text { the two } \\ \text { groups }\end{array} \\ \text { Terazosin } & 88.65 \pm 21.28 & 52.58 \pm 13.10 & p<0.001 & 36.06 \pm 12.38 & 40.70 \pm 13.9 & p<0.001 \\ \text { Tamsulosin } & 87.26 \pm 23.05 & 43.03 \pm 12.50 & p<0.001 & 44.23 \pm 16.91 & 50.68 \pm 14.54 & \end{array}$

In this study, among terazosin group, postural hypotension, dizziness, headache, hypotension (Lying), rhinitis and asyhenia were $9.6 \%, 19.35 \%, 12.90 \%, 6.45 \%, 0 \%, 6.45 \%$ respectively. In the tamsulosin group, these were $0 \%, 6.45 \%$, $3.2 \%, \%, 3.2 \%$ and $3.2 \%$ respectively ( Table 7 ).

Table 7: Adverse effects of terazosin and tamsulosin in follow up visit.

\begin{tabular}{lcc} 
Effects & $\begin{array}{c}\text { Terazosin } \\
\text { group (\%) }\end{array}$ & $\begin{array}{c}\text { Tamsulosin } \\
\text { group (\%) }\end{array}$ \\
Postural hypotension & 9.67 & 0 \\
Dizziness & 19.35 & 6.45 \\
Headache & 12.90 & 3.2 \\
Hypotension (Lying position) & 6.45 & 0 \\
Rhinitis & 0 & 3.2 \\
Asthenia & 6.45 & 3.2 \\
\hline
\end{tabular}

\section{DISCUSSION}

Benign prostatic hyperplasia is a condition of ageing male. It is well established that incidence of BPH risk increases with age. Alpha receptor blockers generally improve urinary symptoms andpeak urinary flowrates 2 to 4 weeks after introduction of the therapy?.

In this study age range was 45-80 yrs. with a mean for terazosin group was $64.23 \pm 6.63$ yrs. and tamsulosin group was $64.13 \pm 6.29 \mathrm{yrs}$. The results of age of two group were statistically insignificant $(\mathrm{p}>0.05)$.

Base line mean of IPSSS in terazosin group was $15.84 \pm 11.85$ and in tamsulosin group was $15.71 \pm 1.90$ points.Base line Qmax of terazosin group was $12.32 \pm 1.05 \mathrm{ml} / \mathrm{sec}$ and tamsulosin was $12.55 \pm 1.26 \mathrm{ml} / \mathrm{sec}$ respectively. Base line PVR of terazosin group was $88.55 \pm 21 \mathrm{ml}$ and tamsulosin group was $87.26 \pm 23.25 \mathrm{ml}$. All baseline parameters like Qmax, IPSS, PVR in both the groups were statistically insignificant. So these factors did not affect study.

Patients having specific drugs in particular group continuously for 2 months and follow up done by taking different parameters.Mean IPSS after 2 months in terazosin group was $9.52 \pm 1.86$ and $8.48 \pm 1.15$ in tamsulosin group. Both showed significant improvement from base line values $(p<0.05)$. There was more percentage reduction of IPSS points in tamsulosin at follow up visit in comparison with terazosin $(46.02 \pm 10.21$ Vs $39.8 \pm 17.78)(\mathrm{p}<0.05)$. Qmax improvement was higher in tamsulosin than terazosin in follow up visit $(32.20 \pm 5.33 \%$ Vs 24.61 \pm 7.97$)(\mathrm{p}<0.001)$. 
Mean PVR after 2 months in terazosin group was $52.58 \pm 13.10$ $\mathrm{ml}$ and tamsulosin group was $43.03 \pm 12.5 \mathrm{ml}$. Percentage improvement of PVR was higher in tamsulosin group $(50.68 \pm 14.54$ Vs $40.7 \pm 13.9)(\mathrm{p}<0.001)$. Results of this study revealed maximum effect of terazosin and tamsulosin in between 8-12 weeks. This result is compatible with another study ${ }^{10}$. A study showed maximum urinary flow rate improved to a greater extent in tamsulosin group $(1.6 \mathrm{ml} / \mathrm{sec} .16 \%)$ than placebo $^{11}$. Similar effect has been found in other studies ${ }^{12,13}$. A separate study done with 1-10mg of terazosin titration doseshowed 13\% more Qmax improvement in terazosin group than placebo (Terazosin minus placebo) ${ }^{14}$

The most common adverse effect we found was headache, asthenia, dizziness and postural hypotension. Terazosin group showed more postural hypotension, headache than tamsulosin group. This study results are compatible with other study ${ }^{15}$.
They also showed incidence of adverse effects by administration of tamsulosin was less than that of terazosin group $(13 \%$ and $50 \%$ respectively $(\mathrm{p}<0.01)$. This is supported by findings of other studies ${ }^{16,17,18,19}$.

\section{CONCLUSION}

It can be concluded that tamsulosin $0.4 \mathrm{mg}$ once daily dose and terazosin 1-2mg incremental dose at least for 8 weeks both are effective in relieving symptoms of BPH but tamsulosin is superior to terazosin in improvement of total IPSS ( $<<0.05)$, Qmax $(p<0.001)$ and PVR $(p<0.001)$ at the end point. The incidence of adverse events by administration of tamsulosin was less than that by terazosin. So, tamsulosin appears to have more efficacy and safety than terazosin in symptomatic $\mathrm{BPH}$.

\section{DISCLOSURE}

All the authors declared no competing interest. 


\section{REFERENCES}

1. Zimmern P. Medical treatment modalities for lower urinary tract symptoms: What are the relevant difference in randomized controlled trial? Eur Urol. 2000; 38: 18-24.

2. Chappte CR: Introduction and concluding remarks. Eur Urol. 2000; 38: 1-6.

3. Berry S J, Coffey D S, Walsh P C and Ewing L L. The development of benign prostatic hyperplasia with age. J Urol. 1984; 132:474479.

4. Canine M, Pfau A, P erlberg S. The use of alpha adnenergic blockers in benign prostaticobstruction. Br.J Urol. 1976; 48: 255-263.

5. Kirby RS: Terazosin in benign prostatic hyperplasia: effects in blood pressure in normotensive and hypertensive men. Br. J Urol. 1998; 82: $373-379$

6. Kirby RS, Bryan J, Eardley I,Chrismas RJ,Liu S,Holmes SAV et al. Finasteride in the treatment of benign prostatic hyperplasia : A urodynamic evaluation.Br J Urol. 1992; 70: 65-72.

7. Lepor H, Willford Wo,Barry MJ. The efficacy of terazosin, finesteride or both in benign prostatic hyperplasia . Veterans Affairs Cooperative Studies Benign Prostatic Hyperplasia Study Group.New Engl J Med. 1996; 335:533-539.

8. Lu- Yao GL, Barry MJ, Chang CH. Transurethral resection of prostate among medicare beneficiaries in the United states: Time treads and outcomes Prostate Patient Outcomes Research Team (PORT). Urology 1994; 44:692-698.

9. Jonler M, Rickman M, Brushiest R C. BPH, Current pharmacological treatment. Drugs. 1994;47:66-81.

10. Brawer M K, Adams G, Epstein H. Terazosin in the treatment of BPH.Arch.Fam.Med.1993;2:929-935.

11. Chappie CR, Wyndaele JJ, Nordling J, Boeminbhaus F, Ypma AF et al. Tamsulosin,the first prostate selective alpha1 A-adrenoceptor antagonist. A meta analysis of two randomized placebo-controlled, multicentre studies In patients with benign prostatic obstruction (Symptomatic BPH). EuropeanTamsulosin Study Group.Eur Uroi. 1996; 29: 155-167.

12. Schulmn CC,Lock TM,Buzelin JM, Boeminghaus, Stephenson TP et al. Long term use of tamsulosin to treat lower urinary tract symptoms/ benign prostatic hyperplasia. JUrol. 2001; 166:1358-1363.

13. Abrams P. Speakman M, Stott M, Arkell D, Pocock R. A dose ranging study of the efficacy and safety of tamsulosin, the first prostate selective alpha $1 \mathrm{~A}$-adrenoceptor antagonist, in patients with benign prostatic obstruction (Symptomatic benign prostatic hyperplasia). Br J Urol. 1997; 80:587-596.

14. Elhilali MM, Ramsey EW,Barkin J. A multi center,randomized, doubleblind,placebo- controlled study to evaluate the safety and efficacy of terazosin in the treatment of benign prostatic hyperplasia. Urology. 1996; 47: 335-342.

15. Na YJ, Guo YL, Gu FL. Clinical comparison of selective and non-selective alpha 1A-adrenceptor antagonist for bladder outlet obstruction associated with benign prostatic hyperplasia: Studies on tamsulosin and terazosin in Chinese Tamsulosin Study Group. J Med. 1998; 29:289-304.

16. Tewari A, Narayan P. Alpha-adrenergic blocking drugs in the management of benign prostatic hyperplasia: Interaction with antihypertensive therapy .Urology. 1999; 53: 14-20.

17. Okada H, Kamidono S, Yoshioka T, Okuyama A, Ozono S et al. A Comparative study of terazosin and tamsulosin for symptomatic benign prostatic hyperplasia in Japanese patients. BJU-Int.2000; 85:676-681.

18. Tsujii T. Comparison of prazosin, terazosin and tamsulosin in the treatment of symptomatic benign prostatic hyperplasia : A short term open, randomized multicenter study. BPH Medical therapy Study Group. Benign prostatic hyperplasia. Int J Urol. 2000; 7: 199-205.

19. Lee M. Tamsulosin for the treatment of benign prostatic hypetrophy. Ann Pharmacother .2000; 34: 188-199. 